\title{
Incubation study of the stromatolyte as a natural source of liming material for management of acid soil
}

RAHULDEV BEHERAAND NIGAMANANDABEHERA

Received : 01.02.2016; Revised : 04.04.2016; Accepted : 30.04 .2016

MEMBERS OF RESEARCH FORUM:

Corresponding author : RAHUL DEV BEHERA, Krishi Vigyan Kendra (O.U.A.T.) MALKANGIRI (ODISHA) INDIA

Email: rahuldevbehera65@gmail.com

Co-authors :

NIGAMANANDA BEHERA, Krishi

Vigyan Kendra (O.U.A.T.)

MALKANGIRI (ODISHA) INDIA

\section{Summary}

The possibility of using the stromatolyte as a soil amendment in an acid soil was investigated. Stromatolyte contained 79 per cent calcium carbonates plus small amount of magnesium and sulphur. An incubation study was conducted with an acid soil upto 50 days and the treatments included various doses of stromatolyte (0.1, 0.2 and $0.3 \mathrm{LR}$ ) with and without FYM. Results indicated the application of different doses of stromatolyte raised the $\mathrm{pH}$ from 5.1 to 6.2 and maintained from $14^{\text {th }}$ to $28^{\text {th }}$ days of incubation period. But when these different doses of stromatolyte mixed with FYM, it raised the $\mathrm{pH}$ from 5.4 to 6.4 and maintained from 21 to $28^{\text {th }}$ days of incubation period.The application of different doses of stromatolyte neutralised the acidity (from 1.13 to $0.62 \mathrm{Cmol}\left(\mathrm{P}^{+}\right) / \mathrm{kg}$ ), exchangeable $\mathrm{Al}^{+3}$ (from 0.60 to $0.43 \mathrm{Cmol}\left(\mathrm{P}^{+}\right) / \mathrm{kg}$ ) and exchangeable $\mathrm{H}^{+}$(from 0.50 to $0.19 \mathrm{Cmol}\left(\mathrm{P}^{+}\right) / \mathrm{kg}$ ). But the combine application of different doses of stromatolyte with FYM neutralised the acidity (from 1.08 to $0.54 \mathrm{Cmol}\left(\mathrm{P}^{+}\right) / \mathrm{kg}$ ), exchangeable $\mathrm{Al}^{+3}$ (from 0.56 to $0.40 \mathrm{Cmol}\left(\mathrm{P}^{+}\right) / \mathrm{kg}$ ) and exchangeable $\mathrm{H}^{+}\left(0.49\right.$ to $0.04 \mathrm{Cmol}\left(\mathrm{P}^{+}\right) /$ $\mathrm{kg}$ ) more. The application of ST @ $0.3 \mathrm{LR}$ mixed with FYM raised the $\mathrm{pH}(6.4)$ and neutralised the acidity $\left(0.54 \mathrm{Cmol}\left(\mathrm{P}^{+}\right) / \mathrm{kg}\right)$, exchangeable $\mathrm{Al}^{+3}\left(0.40 \mathrm{Cmol}\left(\mathrm{P}^{+}\right) / \mathrm{kg}\right)$ and exchangeable $\mathrm{H}^{+}$ $\left(0.04 \mathrm{Cmol}\left(\mathrm{P}^{+}\right) / \mathrm{kg}\right)$ more compared to the other treatments.

Key words : Stromatolyte, $\mathrm{pH}$, Exchange acidity, Acid soil

How to cite this article : Behera, Rahul Dev and Behera, Nigamananda (2016).Incubation study of the stromatolyte as a natural source of liming material for management of acid soil. Asian J. Soil Sci., 11 (1) : 120-125 : DOI : 10.15740/HAS/AJSS/11.1/120-125. 